\title{
WOODLANDS LABORATORY OF THE ABITIBI POWER \& PAPER COMPANY, LIMITED
}

\section{BY GEORGE P. BRECKENRIDGE ${ }^{1}$}

Perpetuation of our forests through management, in our age, must be brought about by experiment and research. It has long been the desire of our Company to establish an area on which such a program might be put into action. The Company's chief concern is the production of pulpwood with which to supply the mills. To do this in perpetuity, regeneration of supply is necessary. The Woodlands Laboratory was established for the purpose of testing methods of improved forestry practice to determine their practical value and application.

The Laboratory is a pilot plant in that it is producing merchantable products by the application of silvicultural methods on a commercial scale. It is an applied research center rather than one of fundamental fact-finding research. We are endeavoring to determine practical methods of improving the quantity and quality of regeneration and of improving stocking. The costs of these endeavors will then be evaluated against the results obtained in terms of adaptability to regular logging procedures or modifications thereof.

The Laboratory is located on Company freehold land, that which is known as G.T.P. Block III, about 60 miles northwest of the Lakehead. This Block is one of ten originally granted to the Grand Trunk Pacific Railway in 1905 by the Province of Ontario as a construction subsidy. Abitibi leased cutting rights from the railway in 1925 until the Blocks were sold to the Company in 1951. The westerly two-thirds of the Block, roughly 40,000 acres, has been set aside for the Laboratory. A variety of sites exists, representative of the district. Road chances are fair to excellent as soils range from boulder-paved swamps to rolling jackpine plains. Twenty-eight per cent of the area consists of water and muskeg. The land is non-agricultural, but better than average forest sites do exist.

A fire protection system is feasible on development of the block.

In the matter of accessibility, the area is crossed by both C.N.R. and C.P.R. rail lines and the Trans-Canada Highway.

As to timber stands, the majority are young growth. Only $12 \%$ of the area appears to be in stands 60 years of age and older. These consist of stands of pure poplar, spruce, jackpine and mixtures of these, with birch. In the older stands treated or examined to date, the only regeneration encountered has been poplar and balsam, which ranges from scattered to adequate. The balance of the stands are a result of fires, the major one of which occurred around 1913. These are predominantly jackpine with scattered patches containing spruce under-story. However, younger stands are better suited to experimental work in that effects are more readily apparent, and silvicultural measures have a better chance of success.

The development work was begun in 1952. A study was made of stands and topography. A localized ground check-cruise was done to substantiate

'Superintendent, Woodlands Laboratory, Abitibi Power and Pager Company Limited, Raith, Ontario. 
inventory data used in preparing new type maps from existing 1320 feet/inch photographs. A preliminary road location line was run and development cost estimates drawn. Volumetric estimates were compiled and a basic operating plan constructed.

Of the total area, the first unit of 20,000 acres is being developed. The scope of the project has been set at 3,000 cunits per year as this was considered in keeping with the sustained yield capacity of the first unit.

To develop this first unit, we have built eight miles of all-weather road, a ten-car double end loading spur, and a 25 -man portable camp.

The equipment allocated to the project includes a 5-ton general purpose truck, a D-6 tractor with bulldozer and winch, a station wagon, light plant, horses, and the usual camp, logging, and fire protection equipment.

The writer, as superintendent, is responsible for all phases of the operation. Mr. Leo Vidlak, who has had extensive European experience in commercial forest management, is responsible to me for silvicultural methods and their application.

Mr. J. B. Matthews, Chief Forester for the Company, was the leading proponent of the Laboratory and is the present director. An advisory council, made up of Head Office and Divisional Foresters of the Company, meets once or twice a year in the Laboratory to discuss and plan for work underway and proposed. While this is a Head Office project, we are assisted materially by the Lakehead Woodlands Division in the matters of purchasing, supply and accounting.

For purposes of planning and recording, the first unit has been broken down into compartments of approximately 500 acres. These are further divided into sub-compartments of from 1 to 50 acres, depending on composition and treatment required or implemented. Each sub-compartment is described on records as to type and composition, plus a statement as to whether or not any regeneration exists before cutting. Also recorded are the treatment given, date of treatment, reasons for specific treatment, costs, whether work done was on a daywork or piecework basis, volume of products removed and results.

Abitibi's Lakehead Woodlands Division has established a number of permanent sample plots on the area and plans to enlarge the series.

Mr. Stan Losee and Mr. Vince Van Vlymen of Iroquois Falls Division have initiated a study of soils and sites in order to develop a classification of sites through which treatments and results may be correlated.

The Laboratory operates on a budget, its net cost being within that of the Company's budgeted appropriation for research. Revenues are derived from the sale of our pulpwood to the Company's mills at the Lakehead, and the sale of fuelwood or lumber, when supply and demand coincide, to other Company camps in the district.

Our labor force is drawn from the Lakehead supply of woods labor. It is intended that the project operate as near as possible on a year-round basis. To date we have succeeded in making it an eleven-of-twelve month proposition. With this feature as a selling point, we are attempting to build up a permanent force. We have the nucleus, but it is a slow process.

The major forestry problems being attacked are the encouragement of advance growth and regeneration and the improvement of species composition. 
The type of silvicultural treatment implemented is dictated by the examination of the stands themselves. Those treatments attempted to date include the following:

\section{Clear Cutting}

This is done where it is obvious that no special treatment is required.

(1) Where satisfactory regeneration is already established.

(2) As a release of the understory by removal of the entire overstory.

(3) In stands of pure poplar or overmature jackpine.

\section{Partial Clear Cutting}

This constitutes clear cutting of portions of a stand using variations of the common strip method. With a $66^{\prime}$ strip as a base, varying patterns are laid out which lead to the progressive clear cutting of a given area in successive cuts spaced over a period of years. The length of these intervals is dependent upon response of the stand to the preceding treatment. The patterns employed so far are:

(1) Alternate strips; cutting every second, third, or fourth strip.

(2) Group strips; circular patches, one chain in diameter, spaced along a narrow $\left(16^{\prime}\right.$ to $\left.18^{\prime}\right)$ road laid down the center of the strip.

(3) Wedge strips; wedge-shaped patches instead of the circular ones, above.

This method is used in stands of smaller softwood timber where wind risk is to be reckoned with, such as pure spruce, mixed spruce-jackpine on wet sites, and immature jackpine. The wood is produced by the cut and pile method and hauled by team-sleigh on swamp sites, or Drott-loaded onto trucks from bulldozed strips in the young jackpine.

\section{Partial Cutting}

It is intended that these types be harvested in three cuts spaced at approximately five-year intervals, depending on response to treatment. The first, or preparatory cut, is to clean up the stand, removing dead, dying, and damaged trees plus those necessary for crown release.

Stands are marked for cutting with an eye toward stand improvement, seed bed preparation, crown stimulation for seed production, and to develop windfirmness.

Stands so treated are pure spruce and mixed types. In the latter, the first cutting runs heavier to jackpine for in all treatments the favored species is spruce.

One mixed type of approximately 15 acres has been set aside for the purpose of establishing a true selection forest. The initial cutting has begun but is not as yet completed.

These types are cut by the cut-and-skid method using single-horse ground skidding.

\section{Other Treatments}

Various other methods have been tried where the opportunity presented itself. These include: 
(1) Direct seeding with a walking stick planter. We were assisted in this by the Department of Lands and Forests of Ontario who supplied the planter, seed, and technical advice.

(2) Planting - both on cleared areas and underplanting. Bulldozed strip roads in young jackpine and in pure poplar cut-over have been planted with $2 / 2$ white spruce and $2 / 0$ white and black spruce in an attempt to establish future seed source rather than another crop. In open stands of overmature hardwoods with heavy ground cover of alder, mountain maple, and hazel, we used a D-6 bulldozer to strip blade-wide trails through the underbrush. These strips were kept roughly parallel, about 40' apart, standing timber permitting. Coverage of the gross area treated in this manner was about $25 \%$, and the strips were planted with some 4000 trees on a $6^{\prime} \times 6^{\prime}$ spacing. This was intended to re-establish spruce on some of the best forest sites, which are now unproductive.

(3) Scarification is accomplished by three means, to date:

(a) Bulldozing strip roads, alternate strips, in young jackpine.

(b) Ground skidding, single horse, in cut-and-skid areas.

(c) Hand scalping on some of alternate strips to assess value of the extra effort to expose mineral soil for seed bed by means other than bulldozing strip roads.

(4) Slash spreading-the spreading of cone-bearing jackpine slash on both bulldozed strip roads and some of the hand scalped patches.

(5) Brush disposal:

(a) Lopping and scattering-in all types of Method "B", Partial Clear Cut. (b) Burning-On Groups.

(6) Chemical debarking-during spring of 1954, about 7 acres of poplar with a small amount of white birch were treated with commercial sodium arsenite solution, "Altas A". This experiment is not completed yet as it consists of testing peelability during periods ranging from four months to two years following application of chemical.

In summary, the experimental work carried out since the inception of the project has been:

\begin{tabular}{lcr}
\hline $\begin{array}{c}\text { General Class } \\
\text { of Treatment }\end{array}$ & $\begin{array}{c}\text { Number of } \\
\text { Sub-Compartments } \\
\text { Treated }\end{array}$ & $\begin{array}{c}\text { Gross Area } \\
\text { Treated }\end{array}$ \\
\hline Clear Cut & 30 & 168.8 acres \\
Partial Clear Cut & 52 & 434.8 acres \\
Partial Cut & 42 & 215.9 acres \\
Planting & 12 & 101.2 acres \\
Seeding & 3 & 2.5 acres \\
Chemical Debarking & 4 & 6.9 acres \\
Scarification (Special) & 2 & 26.0 acres \\
Slash Spreading & 3 & 3.8 acres \\
Brush Disposal & 12 & 7.2 acres \\
\hline Total Treated & 160 & 967.1 acres \\
\hline
\end{tabular}

The cutting treatments listed above yielded 9866 cunits, and 2162 cunits were produced in clearing campsite and road rights-of-way. 
It is regretted that it is not yet possible to report anything conclusive from the results of our experiments. It can be appreciated that the rate of reaction and development of pulpwood species does not lend itself to such early appraisal of the effectiveness of such efforts. Meanwhile, we are going ahead, doing something, recording what we have done, and waiting. We would be happy to have interested parties see these attempts and grateful for the opportunity to see those of others.

It may be that costs of these experiments are not yet applicable to normal operations. However, they can be considered an investment. The determining of these costs and making possible the evaluation of the results and/or returns are the reasons for establishing the Woodlands Laboratory. 